\title{
US firms tipped for contract to run UK physics laboratory $\begin{aligned} & \text { a ride on state } \\ & \text { lobbying efforts }\end{aligned}$ \\ Livermore hitches
}

London. The running of Britain's National Physical Laboratory (NPL) is likely to be taken on by a US company when the management contract for the laboratory is awarded to the private sector for the first time later this summer.

Two US companies - EDS Scicon, the software giant, and Brown and Root, the engineering contractors - are believed to be favourites to manage a laboratory that, among its many achievements, was the birthplace of radar, Barnes Wallis's Second World War 'dam-busting' bouncing bombs, and one of the world's earliest computers.

Other bidders to run an institution that has since become an international authority on measurement standards and metrology include the nuclear division of Rolls Royce, W.S. Atkins, a British civil engineering company, and Serco, a company that manages laboratories and research establishments.

Britain's Department of Trade and Industry (DTI) will select a contractor after the present shortlist of five is whittled down to two bids by May. The contract is to be announced by June or July, with the successful bidder taking over in October after an interim hand-over period.

The DTI, which is NPL's biggest customer, has promised to guarantee around $£ 28$ million-worth of work each year for the duration of the contract. Peter Clapham, the laboratory's chief executive, says he is confident of winning "substantial additional funds after competitive tendering", as well as other DTI contracts.

The proposed changes have nonetheless attracted considerable criticism. Britain's opposition Labour Party's trade and industry spokesman says he was "speechless" when he heard the news. "I cannot see the sense in this," says Lewis Mooney, MP. "There are some things you can privatize; but a national laboratory dedicated to excellence in standards and measurement is not one of them," Mooney adds.

The laboratory's 750-strong staff, most of whom are scientists, were told of NPL's impending sell-off last Christmas. Most are apprehensive about the future of jobs, intellectual property rights and the transfer of pensions in the newly privatized laboratory.

The recruitment of permanent staff has been in abeyance for more than a year, pending the outcome of the transition to private-sector management. In addition, staff numbers are due to be cut from 611 to 540 by the autumn of 1995 , reflecting the drop in income from the DTI over the past three years from $£ 40$ million to less than $£ 30$ million annually.

Many staff are concerned at the principle of a prized national asset being sold over-

seas. Some also fear privatization - which is referred to officially as 'contractorization' will result in employees currently engaged in basic research being required to switch to more lucrative short-term contract work.

Tony Mansfield, NPL's representative of the Institute of Professionals, Managers and Specialists (IPMS), the labour union that represents many researchers at the laboratory, claims that privatization could compromise NPL's world-class reputation for scientific excellence. "How will it be possible to continue long-term research when we shall all be working on short-term contracts?" he asks.

But Clapham denies that contractorization will turn the laboratory into a glorified

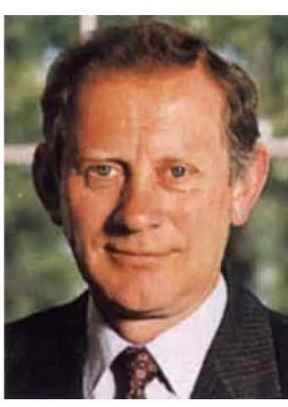

Clapham: says NPL will

maintaln its status. be drawn on whewould be obliged to continue paying for its other long-term - and potentially loss-making — research activities. "Bidders should also assume that a programme of strategic research will continue to be funded from overheads," he says.

Queen Victoria gave the NPL's original 22-acre site in Teddington near London to the Royal Society in 1900. Sir Michael Atiyah, the society's current president, says it is essential that the DTI's contract with NPL's new management should guarantee NPL's scientific excellence.

"We were not in favour of this change," says Atiyah. "But now that the government has decided to go down this road, it is important that NPL's independence and quality of research is not sacrificed."

Mansfield says staff are further irritated by the fact that there was no perceivable need for NPL's management to change hands. It was a decision "motivated more by politics than by science", he says. The proof, he says, lies in the fact that the DTI will still let NPL go, even if none of the bids is deemed satisfactory. "The present management have told us clearly that a decision on awarding the contract will shift to Michael Heseltine, [President of the Board of Trade], if none of the bids is good enough."

Ehsan Masood
San Francisco. Lawrence Livermore Laboratory, prohibited from lobbying government directly, is relying on the efforts of city and government lobbyists to win the \$1.1 billion which it is seeking to build the National Ignition Facility (NIF).

The attendance of laboratory officials at meetings on Capitol Hill has raised concerns that the laboratory is violating strict lobbying restrictions on government-funded institutions. But laboratory, company and city officials say such a presence is not only legal, but vital to ensure that members of Congress are made aware of the nuclear weapons facility that will use lasers to induce self-sustaining fusion.

"People involved in the design [of NIF] at the laboratory have the most detailed information about the facility," says Kathryne Thorpe, director of the Washington office of San Diego-based General Atomics Corp., which employs a consultant to promote the project. She says that the consultant, Pat Fulton, often invites laboratory officials to provide technical information in meetings with congressional staff and interest groups.

The Livermore laboratory would not be able to arrange such meetings on its own, as it is prohibited from promoting its projects to legislators. But officials are allowed to give technical briefings, when invited.

Laboratory representatives stress that they have been careful to avoid any appearance of lobbying. Mike Campbell, associate director for lasers at Livermore, said he is often called on to responds to requests for information from both sides of the debate about the last facility.

Laboratory representatives have held meetings both with labour unions who are anticipating more jobs from the facility, and environmental and anti-nuclear groups, who are opposed to it as a nuclear project. $\mathrm{He}$ said the discussions had provided an opportunity to air concerns on both sides.

Campbell admits that he works closely with Fulton, the General Atomics' lobbyist, who sometimes arranges meetings for him. He says the laboratory is delighted that General Atomics has taken on a strong advocacy role against what he describes as a well-organized campaign against the facility, and has encouraged other supporters to write to their congressmen as well.

The City of Livermore also has been active in lobbying for the giant laser. Cathie Brown, the city's mayor, says the community is keen to preserve high-paying professional jobs that have provided important side benefits such as strong science education in schools. Because the laboratory can't lobby, "the city jumped in front of the whole lobbying effort," Brown said.

Sally Lehrman 